\title{
Peningkatan Pengetahuan dan Keterampilan melalui Penyuluhan dan Simulasi Bantuan Hidup Dasar pada Masyarakat Awam Pesisir di Dusun Kasuari Desa Asilulu Kecamatan Leihitu Kabupaten Maluku Tengah
}

\author{
Knowledge and Skill Enhancement through Counseling and Simulation of Basic Life Support in \\ Coastal Lay Communities in Kasuari Hamlet Asilulu Village, Leihitu District, Central Maluku \\ Regency
}

Suardi Zurimi
Suratno Kaluku*
Adolfina Bumbungan
Department of Nursery, Politeknik
Kesehatan Kemenkes Maluku,
Ambon, Maluku, Indonesia
'email: ners.nano@gmail.com
Kata Kunci
Bantuan Hidup Dasar
Awam pesisir
Nelayan
Pelatihan
Penyuluhan
Keywords:
Basic Life Assistance
Coastal Layman
Fisherman
Training
Counseling
Received: January 2020
Pccepted: April 2020

\begin{abstract}
Abstrak
Ketidakmampuan dalam menangani pasien gawat darurat umumnya disebabkan oleh kegagalan mengenal risiko, keterlambatan rujukan, kurangnya sarana yang memadai dan pengetahuan dan keterampilan masyarakat dalam mengenal keadaan risiko tinggi. Penyuluhan dan pelatihan merupakan upaya yang penting dilakukan untuk meningkatkan pengetahuan dan keterampilan masyarakat awam dalam memberikan pertolongan prehospital. Target luarannya adalah meningkatkan pengetahuan dan ketrampilan masyarakat nelayan tentang Bantuan Hidup Dasar (BHD); mampu mengetahui dan memahami serta mempraktekan tentang BHD. Metode pelaksanaan berupa pemberian kuisioner pre-test, pemberian penyuluhan, pelaksanaan posttest dan pelatihan/simulasi BDH. Hasil yang diperoleh menunjukkan peserta berjumlah 30 orang berprofesi sebagai nelayan (awam) dengan keseluruhan berjenis kelamin laki-laki, peserta mampu memahami materi penyuluhan tentang BHD, adanya peningkatan pengetahuan antara sebelum dan setelah diberikan penyuluhan, serta peserta mampu mempraktikan BHD dengan benar. Kesimpulan yang diperoleh adalah peningkatan pengetahuan dan kemampuan masyarakat dapat menciptakan kemandirian untuk menolong sesuai dengan kompetensi yang didapat dari penyuluhan dan pelatihan.
\end{abstract}

\begin{abstract}
The inability to deal with emergency patients is generally caused by failure to recognize risks, late referrals, lack of adequate facilities, and community knowledge and skills in recognizing high-risk situations. Counseling and training are important efforts to improve the knowledge and skills of ordinary people in providing prehospital help. The target output is to increase the knowledge and skills of the fishing community about Basic Life Assistance (BHD); able to know and understand and practice BHD. The implementation method is in the form of giving pretest questionnaires, providing counseling, conducting post-tests, and $\mathrm{BDH}$ training/simulations. The results obtained showed that 30 participants were working as fishermen with all-male sex, participants were able to understand counseling materials about BHD, there was an increase in knowledge between before and after counseling, and participants were able to practice BHD correctly. The conclusion obtained is an increase in community knowledge and the ability to create independence to help by the competencies obtained from counseling and training.
\end{abstract}




\section{PENDAHULUAN}

Masyarakat pesisir adalah orang yang tinggal di daerah pesisir dan sumber kehidupan ekonominya bergantung secara langsung pada pemanfaatan sumberdaya laut dan pesisir. Sebagian besar penduduk yang tinggal di wilayah pesisir merupakan masyarakat miskin. Kondisi ini disebabkan keterbatasan kemampuan dan pengetahuan, terbatasnya akses terhadap permodalan, teknologi, informasi dan pasar, serta keterbatasan masyarakat dalam keterlibatan untuk pengambilan keputusan alokasi sumberdaya pesisir dan pulau-pulau kecil (Lasabuda, 2013).

Maluku merupakan salah satu provinsi bahari di Indonesia dan sebagian besar masyarakat hidup sebagai nelayan dan tinggal di daerah pesisir. Sebaran masyarakat Dusun Kasuari adalah hidup di daerah pesisir yang berhadapan dengan lautan dimana mata pencaharian utama adalah nelayan. Letak dusun Kasuari dengan pelayanan kesehatan (puskesmas) dibatasi oleh lautan dengan jarak tempuh 30 menit menggunakan speed boat. Hal ini membuat masyarakat tidak terlalu peka dengan masalah kesehatan dan terbiasa hidup mandiri namun tidak tahu akan tindakan-tindakan mandiri dalam menangani sebuah masalah kegawatdaruratan (Kusumaningrum et al., 2013).

Berdasarkan data yang diperoleh di masyarakat Dusun selama ini jarang terjadi kecelakaan berupa tenggelam, namun masyarakat ingin tahu akan penanganan pertama pada kasus tenggelam. Hal ini didasari pada lokasi dusun yang jauh dari tenaga penolong (paramedis dan medis) dan tempat pertolongan (Puskesmas), sehingga masyarakat berkeinginan kuat untuk bisa secara mandiri melakukan cara pertolongan (bantuan hidup dasar) pada kasus kecelakaan yang terjadi di laut, salah satunya adalah tenggelam (Usman et al., 2010).

Tenggelam adalah penyebab utama ketiga kematian akibat kecelakaan yang tidak disengaja di seluruh dunia, dan perkiraan global secara signifikan didapatkan bahwa masyarakat meremehkan masalah kesehatan terkait dengan tenggelam. Anak-anak, pria dan individu dengan peningkatan akses ke air paling berisiko tenggelam (Yuniarti, 2013). Salah satu pencegahan yang penting dilakukan untuk meminimalisir resiko tenggelam adalah melakukan pencegahan, yaitu dengan memberikan pemahaman akan factor resiko dan memberikan edukasi akan penyelamatan dan bantuan hidup dasar (World Health Organization, 2017). Bantuan Hidup Dasar (BHD) merupakan tindakan untuk mempertahankan jalan nafas dan membantu pernafasan dan sirkulasi tanpa menggunakan alat selain alat bantu nafas sederhana. Kombinasi nafas bantuan dan kompresi dada disebut resusitasi jantung paru (RJP). (Soar et al., 2013).

Ketidakmampuan dalam menangani pasien gawat darurat umumnya disebabkan oleh kegagalan mengenal risiko, keterlambatan rujukan, kurangnya sarana yang memadai dan pengetahuan dan keterampilan masyarakat dalam mengenal keadaan risiko tinggi secara dini yang harus dilakukan secara efektif dan efisien. Kesalahan atau ketidaktepatan pemberian pertolongan pertama pre hospital dalam melakukan pertolongan dapat menyebabkan kecacatan atau kematian penderita gawat darurat. Upaya yang harus dilakukan untuk meminimalkan angka kematian penderita gawat darurat harus mempersingkat response time (Agustini et al., 2017; Darwati et al., 2016).

Peningkatan pengetahuan masyarakat dalam upaya pemberian pertolongan pertama prehospital perlu dilakukan. Masyarakat yang tidak paham tentang pemberian pertolongan pertama akan cenderung memberikan pertolongan seadanya tanpa memikirkan tindakan yang dilakukan itu tepat atau tidak. Selain itu, masyarakat awam biasanya hanya menunggu tim penolong datang tanpa memikirkan bagaimana kondisi 
korban yang akan ditolong padahal masyarakat awam dikatakan sebagai penolong pertama dan utama (Putri et al., 2019; Ambarika, 2017). Penyuluhan dan pelatihan merupakan upaya yang penting dilakukan untuk meningkatkan pengetahuan dan keterampilan masyarakat awam dalam memberikan pertolongan prehospital. Penyuluhan dan pelatihan ini baik diberikan sejak usia muda untuk menciptakan generasi muda yang berkompeten dalam mengaplikasikan serta mensosialisasikan cara untuk memberikan pertolongan prehospital (Santosa \& Trisnain, 2019).

Demi meningkatkan pengetahuan dan keterampilan masyarakat awam di pesisir untuk memberikan pertolongan BHD yang tepat, maka berdasarkan analisis tim pengabdi serta hasil penjajakan dengan Dusun Kasuari untuk diberikan solusi yaitu melakukan penyuluhan dan pelatihan BHD untuk masyarakat awam dengan sasaran adalah masyarakat yang berprofesi sebagai nelayan.

\section{METODOLOGI}

Metode penyuluhan dan pelatihan BHD yang digunakan untuk memberdayakan masyarakat awam diharapkan adalah meningkatkan pengetahuan dan ketrampilan masyarakat nelayan dan tentang Model Teknik BHD Sederhana Awam Pesisir, mampu mengetahui dan memahami tentang Pengertian, prosedur dan tahapan Model Teknik BHD Sederhana Awam Pesisir, mampu memahami dan mempraktekan tentang Model Teknik BHD Sederhana Awam Pesisir, yaitu Hal-hal yang perlu dilakukan, Tahapan dan Evaluasi BHD.

Penjajakan dan koordinasi dilaksanakan pada tanggal 89 Juli 2019, yaitu berkoordinasi dengan pihak Desa Asilulu dan Pihak Puskesmas Negeri Lima selaku penanggung jawab pemerintahan dan penanggung jawab pelayanan kesehatan pada Dusun Kasuari.
Selanjutnya pada tanggal 8-9 Oktober 2019, tim pengabdi melakukan kunjungan lapangan ke Dusun Kasuari untuk penjajakan dan penentuan kepastian waktu pelaksanaan serta persiapan lokasi dan peserta yang nantinya akan terlibat pada saat kegiatan.

Kegiatan inti penyuluhan dilakukan pada tanggal 15 - 17 Oktober 2019 bertempat di Ruang Kelas SMP 7 Satu Atap Leihitu, dengan tahapan kegiatan yaitu pelaksanaan pemberian kuisioner pre-test, pemberian penyuluhan, pelaksanaan post test. Pada tanggal $24-26$ Oktober 2019 kegiatan pelatihan/simulasi tahapan yang dilakukan adalah menyiapkan lokasi pelatihan, menyiapkan panthoom, melakukan demonstrasi model teknik BHD sederhana awam pesisir, membentuk Kelompok, dan melakukan pengawasan dan bimbingan pada masing kelompok dalam mempraktikan model teknik BHD sederhana awam pesisir.

\section{HASIL DAN PEMBAHASAN}

Peserta berjumlah 30 orang berasal dari masyarakat yang berprofesi sebagai nelayan (awam) dengan keseluruhan berjenis kelamin laki-laki. Rerata umur responden adalah 33 tahun. Rata-rata tingkat Pendidikan peserta adalah SMP (38,2\%) SD (35,3\%) dan S1 (2,9\%). Pemberian kuisioner pre test dilakukan dengan menghadirkan peserta di kelas. Soal pre test disesuaikan dengan Bahasa masyarakat awam yang mana terdiriatas 20 soal tentang BHD dengan pilihan jawaban menggunakan skala likert. Hasil dari pre test ini bermanfaat untuk mengetahui sejauhmana pemahaman masyarakat sebelum dan sesudah diberikan penyuluhan BHD. 


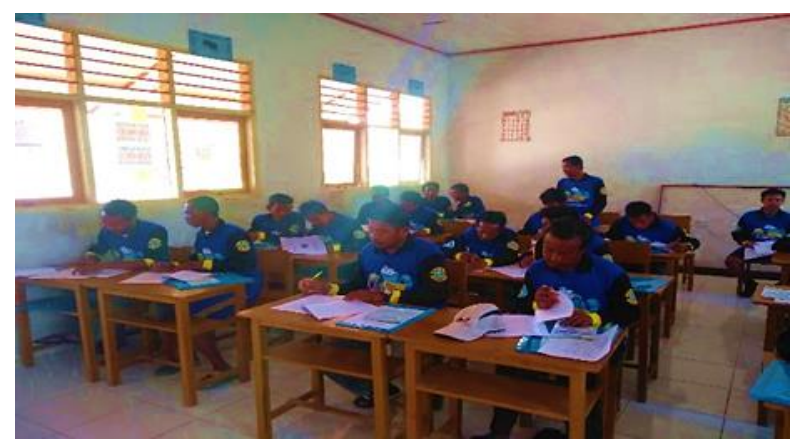

Gambar 1. Pelaksanaan Pre-test

Penyuluhan diberikan oleh tim pengabdi sesuai kepakarannya dengan memperhatikan kebutuhan informasi yang akan disampaikan, target dan sasaran. Materi yang disajikan dalam bentuk power point tentang pentingnya pelatihan bantuan hidup dasar dan langkahlangkah dalam pemberian bantuan hidup dasar sederhana. Metode persentasi yang digunakan adalah ceramah dan diskusi. Peserta sangat antusias menanggapi materi yang diberikan, hal ini ditandai dengan munculnya pertanyaan-pertanyaan yang berkaitan dengan keingintahuan peserta terkait prosedur tindakan BHD Sederhana Awam Pesisir.

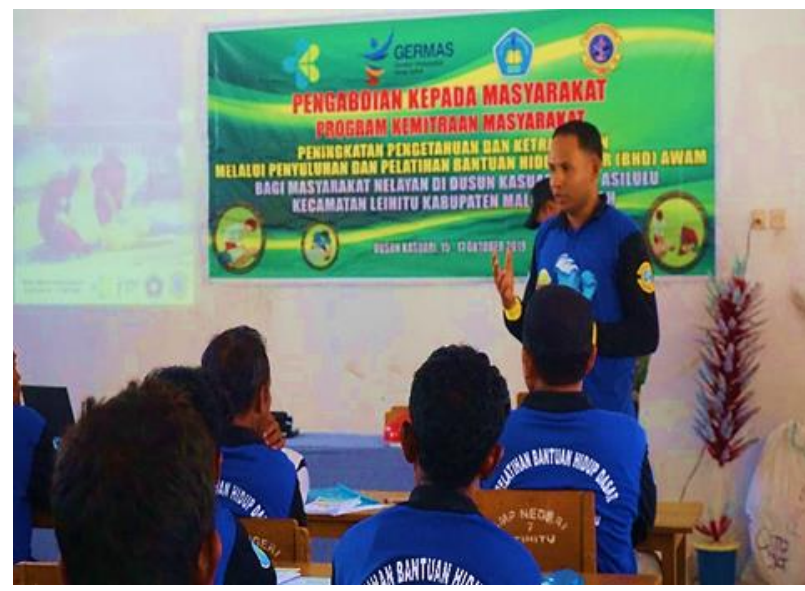

Gambar 2. Penyuluhan

Pemberian kuisioner post test: untuk menilai pemahaman masyarakat setelah diberikan materi penyuluhan dilakukan post test dengan soal dan pilihan jawaban yang sama dengan pre test. Hasil yang diperoleh disajikan pada Tabel I.
Tabel I. Nilai Hasil Pengetahuan Pre Test dan Post Test

\begin{tabular}{|c|c|c|}
\hline No & Pre Test & Post Test \\
\hline 1 & 3.5 & 8.5 \\
\hline 2 & 6 & 9 \\
\hline 3 & 4.5 & 8.5 \\
\hline 4 & 3 & 6 \\
\hline 5 & 7.5 & 9.5 \\
\hline 6 & 3.5 & 7.5 \\
\hline 7 & 5 & 7.5 \\
\hline 8 & 5 & 8.5 \\
\hline 9 & 3.5 & 8 \\
\hline 10 & 3 & 7 \\
\hline 11 & 5.5 & 5.5 \\
\hline 12 & 4 & 8 \\
\hline 13 & 6 & 6 \\
\hline 14 & 6 & 8.5 \\
\hline 15 & 6.5 & 9.5 \\
\hline 16 & 5 & 9 \\
\hline 17 & 4 & 6 \\
\hline 18 & 6.5 & 8.5 \\
\hline 19 & 5 & 9.5 \\
\hline 20 & 6.5 & 9 \\
\hline 21 & 6 & 9 \\
\hline 22 & 6 & 9.5 \\
\hline 23 & 4 & 5.5 \\
\hline 24 & 4 & 5.5 \\
\hline 25 & 4 & 6 \\
\hline 26 & 3.5 & 8 \\
\hline 27 & 5 & 9 \\
\hline 28 & 3.5 & 8 \\
\hline 29 & 4 & 7.5 \\
\hline 30 & 5.5 & 9 \\
\hline
\end{tabular}

Secara statistik hasil dari pelaksanaan pre test dan post test diuji analisis dengan menggunakan analisis paired sample t-Test dengan hasil perolehan adalah $\mathrm{p}=0,001$ $(\mathrm{r}=0,683)$. Hal ini menunjukan bahwa terdapat hubungan pengetahuan antara sebelum dan sesudah dilakukan kegiatan penyuluhan dan simulasi Bantuan Hidup Dasar untuk masyarakat Awam. Apabila tingkat pengetahuan dikategorikan berdasarkan 3 kategori yaitu $<50=$ kurang, $>50-<79=$ Cukup,$>79=$ Baik, maka dari 30 peserta pelatihan yang termasuk pengetahuan kategori cukup adalah 10 orang dan kategori baik adalah 20 orang. Hal ini mengindikasikan bahwa pemberian penyuluhan mengenai model teknik bantuan hidup dasar sederhana sangat mempengaruhi tingkat pengetahuan masyarakat nelayan mengenai materi tersebut

Pelatihan: pelatihan BHD dilakukan oleh tim Pengabdi yang tersertifikasi sebagai pemateri kegawatdaruratan. 
Pelaksanaan dilakukan dengan pemberian checklist tahapan melalukan BHD. Pengabdi memperagakan tahapan simulasi satu persatu berdasarkan checklist yang telah diberikan. Setelah pelatih mempratekkan simulasi teknik bantuan hidup dasar sederhan awam pesisir, peserta bergiliran untuk melakukan simulasi yang dapat dilihat pada Gambar 3 dan 4.

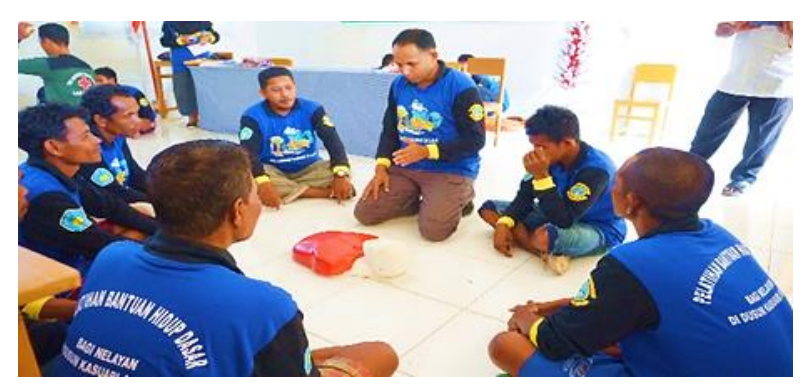

Gambar 3. Pelatih memperagakan BHD

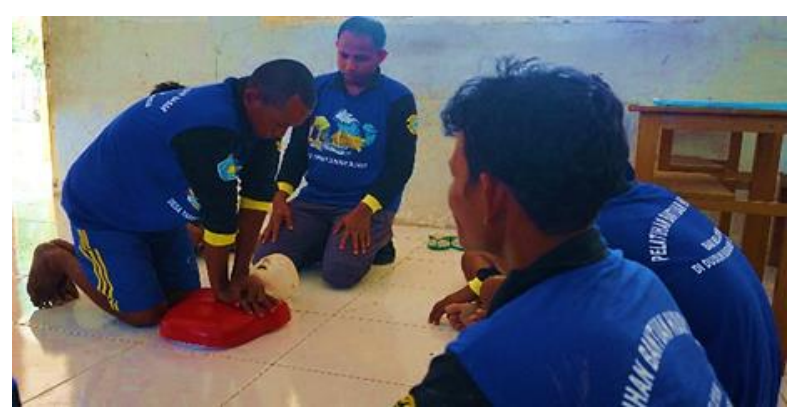

Gambar 3. Peserta mempraktekkan berdasarkan Check List

Penilaian terhadap pelaksanaan simulasi dilakukan secara individu dengan menggunakan checklist pelaksananaan prosedur BHD. Hasil yang didapatkan adalah sebanyak 10 orang (33\%) yang langsung berhasil melakukan simulasi tepat sesuai checklist BHD dengan nilai rata-rata 95 . Sementara sisanya sebanyak 20 orang (67\%) melakukan simulasi ulang sampai dengan mendekati nilai 90 .

Akhir dari pada setiap sesi baik kegiatan penyuluhan maupun pelatihan, pengabdi melakukan survey respon peserta terhadap pemateri dan materi yang disampaikan dengan 5 indikator. Hasil yang didapatkan dari survey tersebut disajikan pada Tabel II. Tabel II menunjukan bahwa sebagian besar peserta rata-rata menilai sangat memuaskan di semua pernyataan baik dari kegiatan penyuluhan maupun pelatihan.

Tabel II. Respon Kepuasan Peserta Terhadap Kegiatan Pengabdian Masyarakat

\begin{tabular}{lcccc}
\hline \multirow{2}{*}{ Pernyataan } & \multicolumn{2}{c}{ Penyuluhan } & \multicolumn{2}{c}{ Pelatihan } \\
\cline { 2 - 5 } & A & B & A & B \\
\hline $\begin{array}{l}\text { Materi penyuluhan } \\
\text { yang disampaikan }\end{array}$ & 32 & 2 & 28 & 6 \\
$\begin{array}{l}\text { Kesesuaian materi } \\
\text { Materi yang }\end{array}$ & 31 & 3 & 30 & 4 \\
$\begin{array}{l}\text { disampaikan relevan } \\
\begin{array}{l}\text { Penguasaan } \\
\text { narasumber }\end{array}\end{array}$ & 30 & 4 & 28 & 6 \\
$\begin{array}{l}\text { Sikap narasumber } \\
\text { A= sangat memuaskan, B=Memuaskan }\end{array}$ & 31 & 3 & 25 & 9 \\
\end{tabular}

\section{KESIMPULAN}

Berdasarkan pemaparan seluruh kegiatan penyuluhan dan pelatihan Bantuan Hidup Dasar (BHD) Sederhana di Dusun Kasuari Desa Asilulu, maka dapat disimpulkan bahwa sejumlah target luaran yang sudah tercapai diantaranya peserta mampu memahami materi penyuluhan tentang Model Teknik BHD Sederhana Awam Pesisir, Adanya peningkatan pengetahuan antara sebelum dan setelah diberikan penyuluhan, serta peserta mampu mempraktikan Teknik BHD Sederhana Awam Pesisir dengan benar.

\section{UCAPAN TERIMA KASIH}

Kesempatan ini, kami sampaikan rasa terima kasih kepada Direktur Poltekkes Kemenkes Maluku, Camat Leihitu, Pejabat Desa Asilulu, Kepala Dusun Kasuari, Tim Evakuasi Medis Laut Lantamal IX Ambon, SMPN 7 Leihitu Satu Atap, Tokoh Agama dan Tokoh Masyarakat Dusun Kasuari.

\section{REFERENSI}

Agustini, N.L.P.I.B., Suyasa, I.G.P.D., Wulansari, N.T., Dewi, I.G.A.P.A., Rismawan, M. 2017. Penyuluhan dan Pelatihan Bantuan Hidup Dasar. Paradharma: Jurnal Aplikasi IPTEK. 1(2):68-74. http://dx.doi.org/10.36002/jpd.v1i2.318 
Ambarika, R. 2017. Effectiveness of Simulated Prehospital Care Thought Self-Efficacy Of Community In Giving First Aid On Traffic Accidents Victim. Jurnal Keperawatan. 8(1):2532. https://doi.org/10.22219/jk.v8i1.4012

Darwati, L.E., Desi, S.K., Sulisno, M. 2016. Karakteristik Perawat IGD Puskesmas. Jurnal Ilmiah Permas: Jurnal Ilmiah STIKES Kendal. 6(1):22-27. https://doi.org/10.32583/pskm.6.1.2016.22-

27

Kusumaningrum, B.R., Winarni, I., Setyoadi, S., Kumboyono, K., Ratnawati, R. 2013. Pengalaman Perawat Unit Gawat Darurat (UGD) Puskesmas Dalam Merawat Korban Kecelakaan Lalu Lintas. Jurnal Ilmu Keperawatan: Journal of Nursing Science. 1(2):8390.

Lasabuda, R. 2013. Pembangunan Wilayah Pesisir Dan Lautan Dalam Perspektif Negara Kepulauan Republik Indonesia. Jurnal Ilmiah Platax. 1(2):92-101.

https://doi.org/10.35800/jip.1.2.2013.1251

Putri, R., Safitri, F., Munir, S., Hermawan, A., Endiyono, E. 2019. Pelatihan Bantuan Hidup Dasar Dengan Media Phantom Resusitasi Jantung Paru (Prejaru) Meningkatkan Pengetahuan Dan Keterampilan Bantuan Hidup Dasar Pada Orang Awam. Jurnal Gawat Darurat. 1(1):7-12.

Santosa, W.R.B., Trisnain, A.N.S. 2019. Pengaruh Pendidikan Kesehatan Pre-Hospital Stroke Terhadap Pengetahuan Dan Self-Efficacy Masyarakat Dalam Melakukan Tindakan Pertolongan Pre-Hospital Stroke. Jurnal Gawat Darurat. 1(1):31-36.

Soar, J., Perkins, G.D., Nolan, J. 2013. ABC of Resuscitation (ABC Series) 6th Edition. London, UK: BMJ Books.

Usman, S., Widhyharto, D.S., Maika, A. 2010. Strategi Penciptaan Pelayanan Kesehatan Dasar untuk Kemudahan Akses Penduduk Desa Miskin. Jurnal Ilmu Sosial dan Ilmu Politik (JSP). 13(3):325-352.

https://doi.org/10.22146/jsp.10956

World Health Organization. 2017. Preventing drowning: an implementation guide. Spain: World Health Organization.
Yuniarti, N. 2013. Epidemology Of Trauma Globaly. EJurnal Medika Udayana. 2(10):1-13. 